\title{
ANALYSIS OF THE CURRENT STATE OF RECREATIONAL RESOURCES OF THE NURA RIVER BASIN, THE REPUBLIC OF KAZAKHSTAN
}

\author{
Nurgul RAMAZANOVA \\ L.N. Gumilyov Eurasian National University, Faculty of Natural Sciences, \\ Satpayev Str., 2, 010008 Nur-Sultan, Republic of Kazakhstan, e-mail: nurgulram@gmail.com \\ Sabina TOKSANBAEVA \\ L.N. Gumilyov Eurasian National University, Faculty of Natural Sciences, \\ Satpayev Str., 2, 010008 Nur-Sultan, Republic of Kazakhstan, e-mail: sabina.toksanbaeva@mail.ru

\section{Zharas BERDENOV*} \\ L.N. Gumilyov Eurasian National University, Faculty of Natural Sciences, \\ Satpayev Str., 2, 010008 Nur-Sultan, Republic of Kazakhstan, e-mail: berdenov-z@mail.ru

\section{Zhanar OZGELDINOVA} \\ L.N. Gumilyov Eurasian National University, Faculty of Natural Sciences, \\ Satpayev Str., 2, 010008 Nur-Sultan, Republic of Kazakhstan, e-mail: ozgeldinova@mail.ru \\ Tangal TURSYNOVA \\ L.N. Gumilyov Eurasian National University, Faculty of Natural Sciences, \\ Satpayev Str., 2, 010008 Nur-Sultan, Republic of Kazakhstan, e-mail: tangaltt@mail.ru

\section{Altynbek ZHAKUPOV} \\ Kazakh University of Technology and Business, Department of Management and Tourism, \\ Muhamedhanova Str., 37, 010000 Nur-Sultan, Republic of Kazakhstan, e-mail: jakypov-alt@ mail.ru

\begin{abstract}
Citation: Ramazanova, N., Toksanbaeva, S., Berdenov, Zh., Ozgeldinova, Zh., Tursynova, T. \& Zhakupov, A. (2020). ANALYSIS OF THE CURRENT STATE OF RECREATIONAL RESOURCES OF THE NURA RIVER BASIN, THE REPUBLIC OF KAZAKHSTAN. GeoJournal of Tourism and Geosites, 31(3), 1043-1048. https://doi.org/10.30892/gtg.31316-539
\end{abstract}

\begin{abstract}
The article shows an analysis of the current state of recreational resources in the Nura River basin of the Republic of Kazakhstan. In order to achieve this goal, the recreational sector of the Nura River basin was examined and the extent to which recreational resources are favorable was analyzed. The types of recreational resources of the Nura River basin were researched, where the territory was divided into recreational zones with similar characteristics and the recreational resources were described by zones. The lakes and reservoirs of the Nura River basin for the present period and their current influence on the recreational sector have been analyzed. Maps of the degree of favorable development of the recreational sector, recreational resources and recreational zones of the Nura River basin for the modern period have been compiled.
\end{abstract}

Key words: analysis, recreational resources, basin, research, recreational zones

$* * * * * *$

\section{INTRODUCTION}

The recreational sector is an important component of any state, therefore the Republic of Kazakhstan, the Nura River basin also plays a huge role, first, because it is located in the Central part of the Republic, and secondly, due to the fact that this territory has almost all types of recreational sector. Recreational services to the population and recreational resources are one of the most important socio-economic activities of modern society (Canteiro et al., 2018; Dirin et al., 2014; Tătar et al., 2018; Beketova et al., 2019). The result of activities in the recreational sphere is expressed in improving the health of the population, reducing the incidence of diseases, increasing the time of active life and its duration. Only a full rest allows you to compensate for hard work, successfully adapt to loads and stressful situations, and contributes to progress in production and the economy as a whole (Berdenov et al., 2016; Azhayev et al., 2020; Gavrilov, 2011). Kazakhstan pays serious attention to this industry (Akbar et al., 2020). Despite the difficulties of the transition period, after the Republic gained independence, there is a gradual trend towards increasing the number of sanatoriums, recreation centers, tourist bases, children's camps, other health and treatment institutions, expanding their capacity, improving the quality of service, and developing infrastructure (Aidarkhanova et al., 2015). That is why the study of recreational resources and analysis of the current state is an integral and important part of the development of the tourism sector, and is relevant today as never before (Wendt, 2016; Ionescu et al., 2016; Gozner et al., 2017; Ilieș et al., 2018, 2018; Wendt, 2018; Deac et al., 2019; Indrie et al., 2019; Mikhaylov et al., 2020; Akhmedenov, 2020; Mukayev et al., 2020). Many scientists have been researching basins (Kabiyev et al., 2018; Ramazanova and Dzhanaleyeva, 2012; Darbayeva et al., 2020) and landscape analysis of recreational resources in Kazakhstan (Ozgeldinova et al., 2015; Ramazanova et al., 2019; Ozgeldinova et al., 2019; Nazarova et al., 2019; Mikhaylov et al., 2020).

\section{MATERIALS AND METHODS}

Due to the fact that recreational resources are important for the tourism sector and people in general, the study of recreational resources is necessary and relevant today. The center of the Republic of Kazakhstan is of great importance for the country's economy. Therefore, the territory of the Nura River basin, located in the center of the Republic of Kazakhstan, mostly in the Karaganda region and a small NorthWestern part in the Akmola region, was taken for research.

\footnotetext{
* Corresponding author
} 
The research materials included geographical maps of the Republic of Kazakhstan, atlases, statistical collections and data on the Nura River basin for 2015-2020, scientific publications and results of field and stationary research in 2020 (Mukayev et al., 2020).

To analyze the current state of recreational resources in the Nura River basin by the degree of favorability, cartographic, statistical and comparative-geographical methods were used. The cartographic method was used to analyze cartographic material for the Nura River basin and Central Kazakhstan as a whole, to collect information on maps of the recreational sector, on the relative positions of objects and their sizes. The statistical method was used to review statistical data on recreational resources in order to analyze the current state of recreational resources in the Nura River basin in the Republic of Kazakhstan. The comparative geographical method was used for comparative characteristics for the period 2015-2020 on the state of recreational resources, identification of positive dynamics of the development of the recreational sector, as well as consideration of the negative aspects of the development of this industry. The method of assessing the natural recreational potential of (Stepanova, 2010) was also used by differentiating the territory of the Nura River basin into zones of potential recreational development. A qualitative assessment of the recreational potential of the territory was carried out, that is, the entire territory of the analyzed region was differentiated by zones of potential recreational development. For this purpose, a mapping zoning of the Nura River basin was carried out with the division of the territory into several recreational zones on a geographical basis.

\section{RESULTS DISCUSSIONS}

According to the geography sector of the Academy of Sciences of the Republic of Kazakhstan, the territory of the Nura River basin is located in a steppe zone, within which there are high plains, and a typical hills (Janaleyeva, 2010). By features of climate, land cover and vegetation, the zone is divided into two sub-zones: arid motley-feather-grass steppes and dry narrow-leaved-feather-grass steppes.

Located in the Eastern part of the low mountains of Karkaraly-part of Central Kazakhstan hills, give the area the character of foreststeppe, bringing elements of high-altitude zoning to this area.

The climate is sharply continental, with a significant lack of humidity. Summer is hot and winter is harsh. The transition from winter to summer is fast. The average temperature in January is minus $18-20^{\circ} \mathrm{C}$ (absolute minimum of minus $50^{\circ} \mathrm{C}$ ), in July - plus $18-20^{\circ} \mathrm{C}($ absolute maximum of $+42^{\circ} \mathrm{C}$ ). The duration of the frost-free period is 110-130 days. The winds have a South-westerly direction. Their average annual speed is $3-6 \mathrm{~m} / \mathrm{s}$, the annual precipitation in the plain is $270 \mathrm{~mm}$, in the low-mountain zone reaches $330 \mathrm{~mm}$. There are more than 50 watercourses in the region with a length of more than $10 \mathrm{~km}$, of which three-quarters are temporary. The main waterway is the Nura River. A characteristic feature of most rivers is the lack of constant flow (Kalmenova, 2000). Recreational resources of the Nura River basin are represented by forests, rivers and reservoirs, hunting and fishing grounds, the potential of specially protected natural territories, individual deposits of medicinal waters and mud. This article presents the results of research on the territory of the Nura River basin in the course of field and stationary work on the object of research, including recreational resources. Based on the research results, the territory was analyzed according to the degree of favorable development of the recreational sector, and a map was compiled (Figure 1).

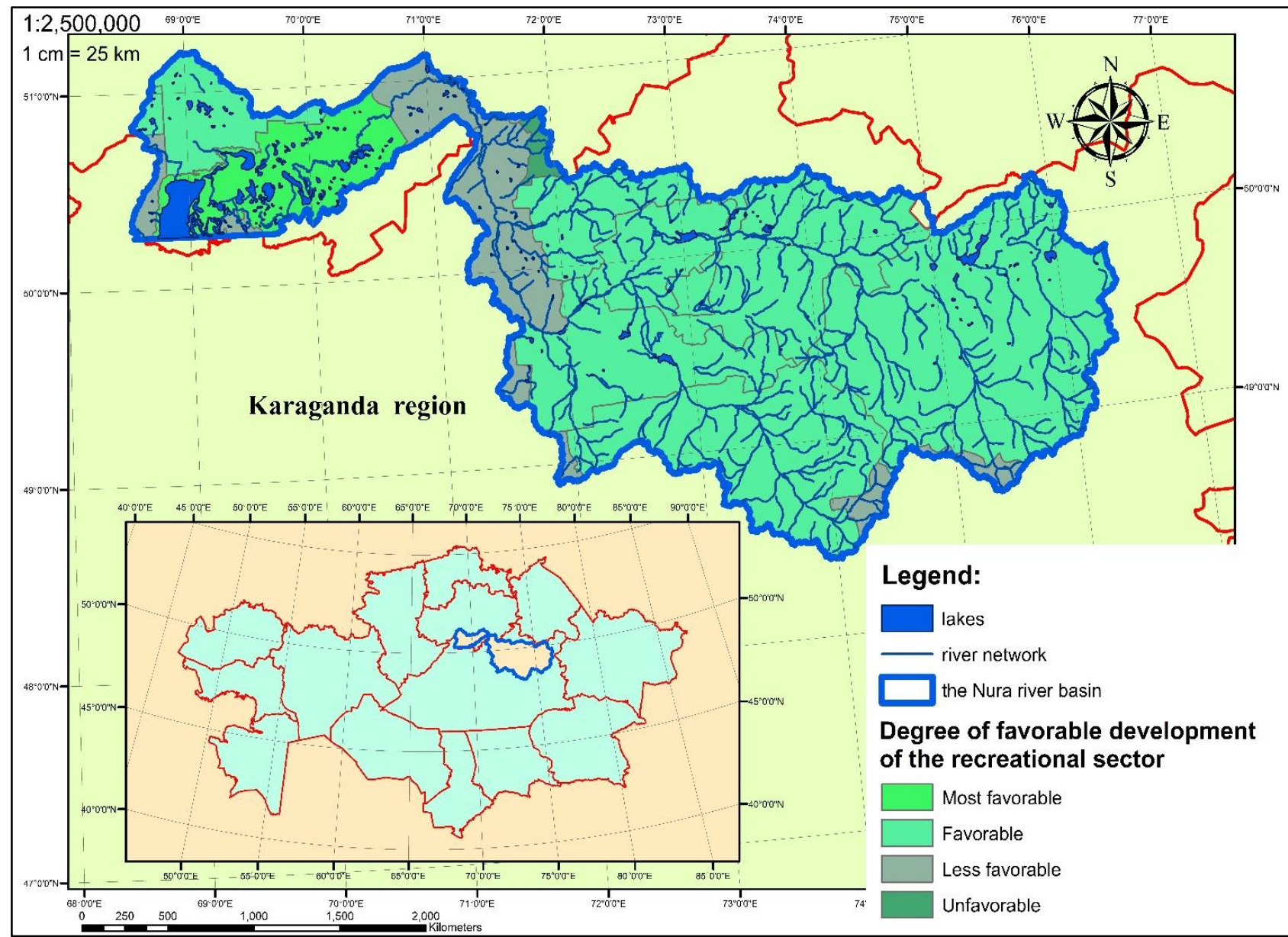

Figure 1. Map of the degree of favorable development of the recreational sector of the Nura River basin

In the course of the study, the most significant recreational area in the basin is the territory of the Karkarala state national park. There are 7 children's recreation and recreation camps for 1750 people, 8 adult recreation centers for 1440 people, 2 resorts for 420 people, 2 tourist 
bases for 480 people, a ski complex, a nature museum, tourist clearings for tent cities, a large number of bizarre natural rock sculptures, parking of primitive man, a developed road network for hiking, horseback riding, cycling and skiing tourist routes.

Among other recreational facilities in the pool, it is necessary to note the sanatorium "Zhartas" in the Abay district near the village of the same name, the sanatorium - preventorium "Samal" in Temirtau, the sanatorium "Zhosaly" in Karaganda, the health center "Bere zka" in Sarani, as well as children's recreation camps in Temirtau, Shakhtinsk, Osakarovsky and Bukhar-Zhyrau districts - their total capacity is about 2000 seats. The area of the Nura River basin is $58,100 \mathrm{~km}^{2}$. The most favorable place is located in the Western part and is $13 \%$, the favorable place for recreation development in the territory of the Nura River basin is located in the South-Eastern part and is $61 \%$ in percentage, as well as a small part in the West with $7 \%$ of the entire territory. The less favorable territory is $15 \%$. Unfavorable territory for recreation development occupies $4 \%$ of the entire territory. Data were obtained from stationary and field observations in 2020 , as well as by analyzing data for the period 2015-2020.

Below is a map of recreational resources of the Nura River basin for the modern period, compiled by the authors personally (Figure 2).

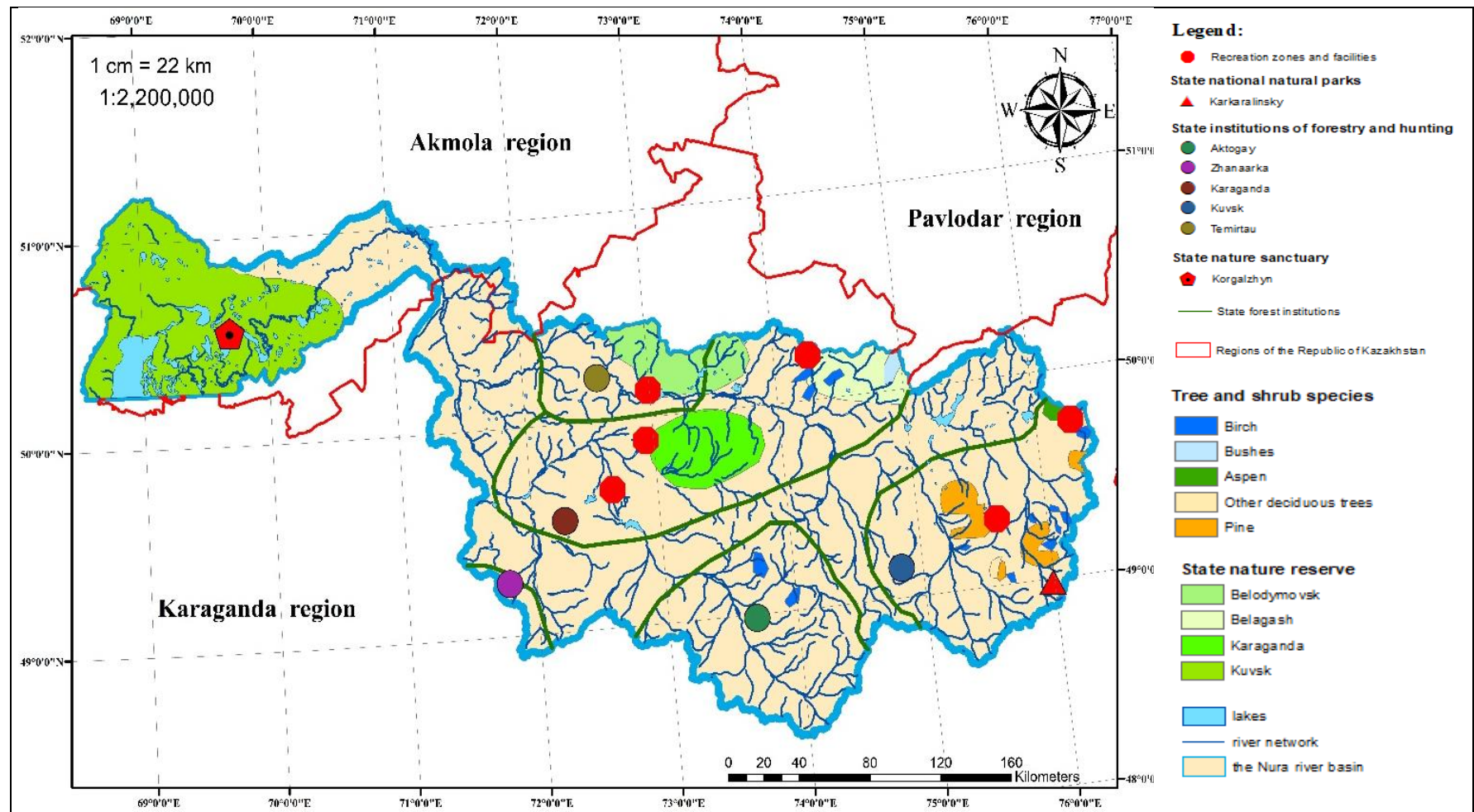

Figure 2. Map of the recreational resources of the Nura River basin for the extant period

A large recreation area is located on the Northern Bank of the Samarkand reservoir, where there are equipped beaches, sports grounds, boat rentals, and fishing in specially designated areas. There is a large ski resort in the vicinity of Temirtau.

Beach areas are also located on the banks of the Sherubai-Nurinsk and other reservoirs, the Nura River, numerous lakes and ponds. Among the active types of recreation of the population, amateur and sports hunting and fishing have become widespread. Almost all administrative districts have hunting farms and fishing facilities, but there are very few modern bases for these types of leisure activities.

Tourism has developed on the territory of the basin; an exceptionally popular tourist attraction is the Korgalzhyn state sanctuary, which is considered "One of the natural pearls of Kazakhstan".

The tourist route "To the land of undisturbed birds" includes a visit to the museum of the sanctuary, four ecological routes of various difficulty categories, walks along the shores of lakes Essey, Sultankeldy, Kokai, and observing the life of numerous species of birds, including rare and unique ones. Other specially protected natural areas within the Nura River basin are also of particular scientific, educational and environmental interest to tourists. As a result of the study, the territory of the Nura River basin areas was divided into zones based on the similarity of territorial and recreational features and a modern analysis of each zone by recreational resources was given.

According to the geographical feature of the Nura River basin it is assumed to allocate 4 potential zones of recreational development:

Western zone №1; Central zone №2; Southern zone №3; North-Western zone №4.

Central №2 and Southern №3 recreational zones of the Nura River basin are forests, the most significant areas of forests are located on this territory. Among them, the largest recreational value is represented by large massifs of pine and mixed forests of the Karkaralinsk state national natural park and the Kuvsk state institution of forestry and hunting (KSIFAH). Most of these forests are located within the areas of the Kazakh hills. Plantings are quite different in age, often with rich undergrowth. Dry forest types are predominant, but fresh forest types are also common at the foot of mountains, in valleys and intermountain areas. In combination with mountainous terrain, open glades, rivers and reservoirs, forests create a special healing microclimate and abound in berries, mushrooms, and rare animals and birds can sometimes be found in them. The area's birch and pine forests are also of known value for recreational use. Pine and birch-aspen forests of Karaganda KSIFAH in its North-Eastern part and soft deciduous forests in the South-Eastern part are of particular recreational interest.

For some types of short-term outdoor recreation, sanitary protection zones of cities with an area of 11618 ha can be used, including around cities: Karaganda -4371 ha; Temirtau -5156 ha; Shakhtinsk -2499 ha; Saran -1604 ha; Abay - 164 ha.

The species composition of green zone plantings is quite diverse. They grow not only unpretentious elm, Loch, maple, but also birch, pine, poplar, apple, soft-leaved ornamental shrubs and even larch.

In the North-Western recreational zone №4, artificial plantings along the K.Satpayev canal prevail, where the species composition is somewhat limited - elm, loch, and shrubs. Small areas of prickly birch and main forests are found in the southern part of the basin of the 
southern recreational zone. The Western recreational zone №1 of the Nura River basin is almost treeless, except for shrub plantations on river floodplains near reservoirs and rare spikes of soft-leaved tree species. There are also hunting grounds on the territory of the Western №1 and southern №3 recreational zones, and almost all zones have rivers and reservoirs.

Below is a map of recreational resource zones in the Nura River basin (Figure 3).

Summarizing the above research on the Nura River basin, recreational resources also include hunting grounds, lakes and reservoirs, and specially protected natural areas. A brief description of the current period for these objects is given below.

Hunting grounds.

Numerous rivers, lakes and other reservoirs are rich in waterfowl, and animals and birds of interest for amateur and sport hunting are found everywhere in the forests. Hunting is conducted both for native fauna and for flying game, the number and diversity of which are among the highest in the Republic.

Modern analysis of lakes and reservoirs in the Nura River basin.

The Nura River basin has a fairly well-developed hydrographic network, and most of the watercourses in its Western part are temporary. There are many lakes on the territory that have not only recreational, but also fishing significance. Some of them are objects of the state nature reserve Fund of national significance (the list is given below) and are of great scientific and environmental value.

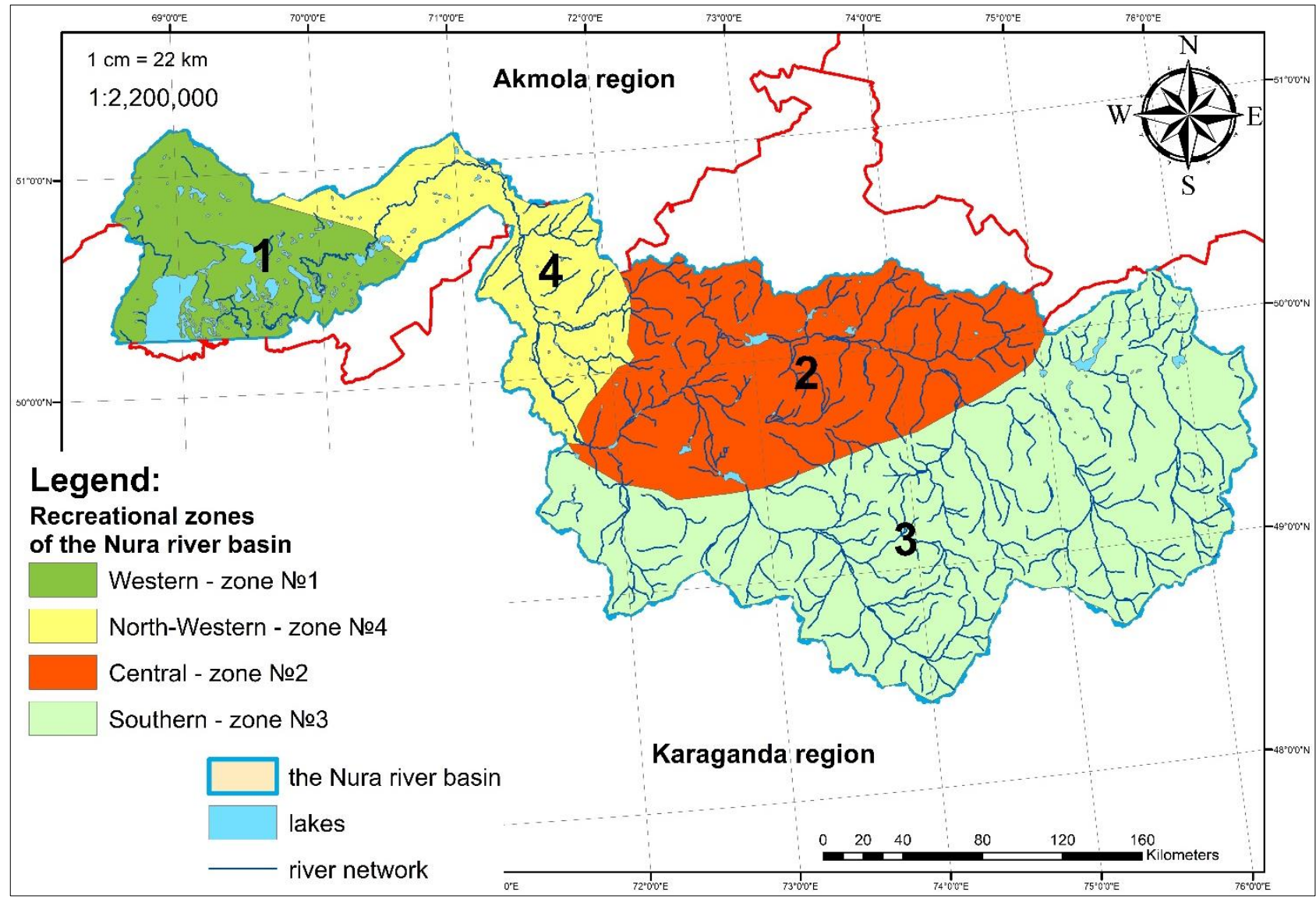

Figure 3. Map of recreational zones of the Nura River basin

The following lakes can be highlighted:

1. Salt Lake "Aschikol", located $40 \mathrm{~km}$ East of the village of Koskol;

2. Karasor lake in Karkaraly district, one of the largest lakes in the basin, highly mineralized (250-350 g/l), has therapeutic mud, traditionally used for balneological purposes;

3. Lake Karakol $10 \mathrm{~km}$ North of Karaganda, whose water is suitable for drinking and agricultural irrigation;

4. Lake Agashtykol near the village of the same name, the water is suitable for drinking and other household needs;

5. Lake Saumalkol, water suitable for all types of use;

6. Lake Balikkol in the Nura area, the water is safe to drink, the object of fishing;

7. Sasykol lake, water suitable for all types of use, fishing facility.

Reservoirs are of great importance in the Nura River basin.

1. Samarkand, located to the East of Temirtau, used for industrial water supply of the Karmetkombinat and irrigation. Its Northern Bank is occupied by a fairly well-equipped recreation area of the population of Temirtau.

2. Sherubay-Nurinsk, located on the river near the village of Topar, used for water supply of the Karaganda industrial district and irrigation, partly for recreational purposes.

3. Intumaksk, located $60 \mathrm{~km}$ West of Karaganda, used not only for water supply, but also for fishing, it is home to 10 species of fish.

4. Botakara, located to the North-East of Karaganda, is used for irrigation and agricultural water supply.

5. Tuzdinsk used for agricultural water supply.

Almost all reservoirs are used for recreational purposes for short-term recreation in the summer, as well as for amateur and sport fishing. The most important artificial water object is the K.Satpayev canal, whose waters are used for industrial, household needs, irrigation, etc. Specially protected natural territories 
Karaganda region has a large and diverse nature reserve fund.

Almost all types of specially protected natural territories that are unique, valuable in ecological, scientific, aesthetic, cultural, tourist and educational terms, natural complexes and objects that have not only regional and national, but also world significance, exist here or are being designed for organization.

\section{CONCLUSION}

The study analyzed the current state of recreational resources in the Nura River basin. The territory of the Nura River basin for the recreational sector was reviewed and analyzed. During the review and research, an analysis was made of the degree of favorability of the development of recreational resources by zones. The most favorable place is located in the Western part of the Western zone No. 1 and is $13 \%$ favorable place for the development of recreation in the Nura River basin is located in the South-Eastern part of the Southern zone №3 and is the percentage of $61 \%$, and a small part in the West $7 \%$ of the whole territory (Figure 3). The degree of favorability in these zones is due to the fact that the Western part of the lake steppe region is rich in fish, waterfowl and migratory game, with its nests and camps on the lakes Korgalzhyn, Kokai, Chagan, Kaibchalkar, Karazhar, Uzynkol, Zhanybek. Only on its reservoirs are rare in beauty pink fla mingos. The unique Korgalzhyn reserve, created in 1968, is also located here. The unfavorable territory located in the North-Western zone №4 is 15\%. Unfavorable territory for recreation development occupies $4 \%$ of the entire territory and is also located in the North-Western zone №4 (Figure 3). In General, the territory of the Nura River basin is favorable for the development of recreational tourism with the correct principle of operation and implementation of plans to improve the situation of the recreational sector.

The types of recreational resources were studied and divided into zones with similar features, and a description of each of the resources by zone was made. The main recreational resources of the Nura River basin are represented by forests, rivers and reservoirs, hunting and fishing grounds, the potential of specially protected natural territories, individual deposits of medicinal waters and mud. Most of them are occupied by state nature reserves and recreation areas, which make up $50 \%$ of the total territory.

The analysis of lakes and reservoirs of the Nura River basin for the modern period and their current impact on the recreational sector was also performed. When studying lakes and reservoirs of the Nura River basin, the current state of recreational resources, considering water resources, shows the dynamics of changes for the better. Previously, these studies were carried out by many Kazakh scientists (Abdreeva et al., 2015). Having made a comparative characteristic based on observations over the last 5 years from 2015 to 2020 based on statistical data of the Nura River basin on the recreational sector, the overall picture of recreation in this region has a positive trend and this is due to state programs aimed at the development of the tourism sector and domestic tourism of the Republic of Kazakhstan. As a result, recreational recreation areas are being created in this region and the state of flora and fauna is improving. If earlier domestic tourism was not so developed, now it is actively developing and popularized among the population of the Republic of Kazakhstan. Considering the issue of the structure of the recreational sphere, it should be noted that while the tourist attractiveness is often caused by the presence of unique and unrepeatable landscapes, cultural and historical heritage, not ordinary geological formations, rich original plant communities and habitats of rare fauna, the actual recreational activity in the Republic, as well as throughout the world, is carried out mainly near water bodies. Construction of holiday homes, summer camps for children and adults, camp sites and beach complexes, and other similar facilities is usually carried out on the banks of rivers, lakes, reservoirs, sea coasts, etc.

The exception is specialized medical institutions, for which the main criteria is the presence of a particular therapeutic factor - mineral waters, therapeutic mud, areas characterized by particularly valuable indicators of sanitary and hygienic conditions, as well as winter recreation and sports facilities. Therefore, it is important to pay special attention to the recreational sector and consider the prospects for the development of recreation and tourism. It should be noted that the territory of the Nura River basin is unique for its unusual structure of lakes, so lake Koktal, located in the Western part of the basin, is distinguished by its unusual system and location in a unique place, lake Tengiz - the "Pearl" of the Korgalzhyn reserve, the habitat of the famous pink flamingos with rich flora and fauna.

The Nura River basin is represented by unique types of forests, rivers and reservoirs, hunting and fishing grounds, specially protected natural territories, individual deposits of medicinal waters and mud, with an extensive system of lakes.

There are 7 natural monuments:

- Boxelder maple, located in the city of Karkaralinsk on the street Ermekova house 13, in the Karaganda region. Tree planting here began in 1914;

- Cave of prehistoric man, is located in the tract Maliksay, 3 kilometers from the city of Karkaralinsk. This is a small stone canyon made of granite slabs and three entrances to the underground. Extreme caves of small size;

- Siberian larch, located on the territory of the Karaganda forestry, 31 quarter, 14-15 allotments. The total area is 5.7 hectares;

- Lake Shaitankol, located at a distance of $5 \mathrm{~km}$ to the West of the city of Karkaralinsk, belongs to the mountain reservoirs, is located in a basin surrounded by a number of hills at an altitude of about 1200 meters. The lake itself, the surrounding forests and mount ains are very beautiful and shrouded in legends;

- Basin lake, located at a distance of $4.5 \mathrm{~km}$ North-West of the city of Karkaralinsk, belongs to the mountain reservoirs;

- Natural monument Siberian Spruce, located in the municipal state institution "Karaganda economy for the protection of forests and wildlife", Karaganda forestry, in the Karaganda region;

- Palatka nature monument, located North of the city of Karkaralinsk. This is a vast depression in the granite wall, safely sheltered from the rain and sun by a giant stone canopy.

The following species of animals also live: wolf, boar, roe, elk, marmot, fox, korsak, polecat, hare, duck, goose, grey partridge, ermine, weasel; rare and endangered species: stipa, festuca valesiaca, artemisia, limonium, carex, calamagrostis, phragmites (Erzhanov, 2001). The development of the recreational sector of this territory is of great cultural and natural significance, as there are rare species of flora and fauna. Among the fauna in the territory of the Nura River basin, you can find grasshopper, tipchak, sagebrush, kermek, sedge, weinik, reed (Bekenov, 1996; Baitenov, 1985).

The current state of recreational resources of the Nura River basin shows that most of the territory is favorable for the development of recreation, and has the potential to become even more improved and developed for human recreation and preservation of the cultural heritage of nature. But also, for the creation of tourist routes in the vicinity of the Nura River basin, at the moment there is not enough developed road infrastructure, which is mostly one of the most important problems of the development of the recreational sector and tourism in Kazakhstan.

\section{REFERENCES}

Abdreeva, Sh.T, Kalmenova, W.A., \& Tursynbaeva, K.S. (2015). Ocenka vodnyh resursov Karagandinskoy oblasti dlya razvitiya rekreacii i turizma [Assessment of water resources of Karaganda region for development of recreation and tourism]. KazNU Bulletin, Geography series, №2 (41), $377-381$ (Russian).

Akhmedenov, K.M. (2020). Tourist and recreational potential of the salt lakes of Western Kazakhstan. GeoJournal of Tourism and Geosites, 30(2spl), 782787. https://doi.org/10.30892/gtg.302spl01-505 
Aidarkhanova, G.S., Saspugayeva, G.Y., Massenov, K.B., Abseitov, E.T., \& Satova, K.M. (2015). Ecological assessment of the quality of crop production supplied to the markets of major cities in Central Kazakhstan. The study of contamination of agricultural plants radionuclides and heavy metals. Oxidation communication, 2 (38), 900-904. https://www.scibulcom.net/jbtar.php?gd=2015\&bk=2

Akbar, I., Yang, Z., Mazbayev, O., Seken, A. \& Udahogora, M. (2020). Local residents Participation in Tourism at a world heritage site and limitations: AksuJabagly state Nature reserve, Western Tian-Shan, Kazakhstan. GeoJournal of Tourism and Geosites, 28(1), 35-51. https://doi.org/10.30892/gtg.28103-450

Azhayev, G., Esimova, D., Sonko, S.M., Safarov, R., Shomanova, Zh. \& Sambou, A. (2020). Geoecological environmental evaluation of Pavlodar region of the Republic of Kazakhstan as a factor of perspectives for touristic activity. GeoJournal of Tourism and Geosites, 28(1), 104-113. https://doi.org/10.30892/gtg.28108-455

Baitenov, M.S. (1985). V mire redkih rasteniy [In the world of rare plants]. Kainar, 95-100, (Russian).

Bekenov, A.B. (1996). Sovremennoe sostoyaniye i perspektivy izucheniya fauny Kazahstana [Current state and prospects of studying the fauna of Kazakhstan]. Karaganda: Izdatelstvo KarGU, 14-19 (Russian).

Beketova, A., Berdenov, Z., Mendybayev, E., Safarov, R., Shomanova, Zh. \& Herman, G.V. (2019). Geochemical Monitoring of Industrial Center for Development of Recreational Areas (On the Example of Khromtau-Don Industrial Hub, Kazakhstan). GeoJournal of Tourism and Geosites, 27(4), 14491463. https://doi.org/10.30892/gtg.27428-447

Berdenov, Z.G., Atasoy, E., Mendybayev, E.H., Ataeva, G., \& Wendt, J.A. (2016). Geosystems geoecological assessment of the basin of rivers for tourist valorization. Case study of Ilek river basin. Geojournal of Tourism and Geosites, 18(2), 187-195. http://gtg.webhost.uoradea.ro/PDF/GTG-2-2016/224_Berdenov.pdf

Canteiro, M., Cordova-Tapia, F. \& Brazeiroc, A. (2018). Tourism impact assessment: A tool to evaluate the environmental impacts of touristic activities in Natural Protected Areas. Tourism Management Perspectives, 28, 220-227. https://doi.org/10.1016/j.tmp.2018.09.007

Darbayeva, T., Ramazanova, N., Chashina, B., Berdenov, Zh., Mendybayev, E., Wendt, J.A. \& Atasoy E. (2020). Modeling soil erosion in the Chagan river of the west Kazakhstan with using RUSLE and GIS tools. J.Environ. Biol., 41, 396-404. http://doi.org/10.22438/jeb/41/2(SI)/JEB-18

Deac, L.A., Gozner, M. \& Sambou A. (2019). Ethnographic museums in the rural areas of Crișana Region, Romania - Keepers of local heritage, tradition and lifestyle. GeoJournal of Tourism and Geosites, 27(4), 1251-1260. https://doi.org/10.30892/gtg.27411-430

Dirin, D.A., Krupochkin, E.P. \& Golyadkina, E.I. (2014). Metodika kompleksnoy otsenki turistsko-rekreatsionnogo potentsiala regiona [Methods of integrated assessment of the tourist and recreational potential of the region]. Geografiya I prirodopolzovanie Sibiri, 18, 64-78, (Russian).

Erzhanov, N.T. (2001). Redkiye ischezayushie mlekopitayushiye Kazahskogo melkosopochnika. [Rare endangered mammals of the Kazakh hills]. Karaganda, 171-174, (Russian)

Gavrilov, A.I. (2011). Razvitie resursnogo potentsiala turizma na regionalnom urovne: Sotsialno-ekonomicheskie faktory [Developing the Regional-Level Resource Potential of Tourism: Socioeconomic Factors]. Problemy teorii i praktiki upravleniya, 11, 50-55 (Russian).

Gozner, M., Tătar, C.F., Stupariu, M. \& Măduta, F.M. (2017). Nature, Photography and Tourism in Bihor-Vlădeasa Mountains (Romania). GeoJournal of Tourism and Geosites, Year X, Volume 20, Oradea-Gdansk, Romania-Poland, Editura Universităţii din Oradea.

Ilies, D.C., Buhas, R., Ilies, M., Ilies, A., Gaceu, O., Pop, A.C., Marcu, F., Buhas, S.D., Gozner, M., \& Baias, S. (2018). Sport Activities and Leisure in Nature 2000 Protected Area - Red Valley, Romania. Journal of Environmental Protection and Ecology, 19, № 1, 367-372.

Ilieș, D. C., Oneț, A., Wendt, J. Ilieș, M., Timar, A., Ilieș, A., Baias, S. \& Herman, G.V. (2018). Study on microbial and fungal contamination of air and wooden surfaces inside of a istorical Church from Romania, Journal of Environmental Biology, vol 39/6, http://www.jeb.co.in/journal_issues /201811_nov18/paper_06.pdf.

Indrie, L., Oana, D., Ilies, M., Ilies, D.C., Lincu, A., Ilies, A., Baias, S., Herman, G.V., Onet, A., Costea, M., Marcu, F., Burta, L. \& Oana, I. (2019). Calitatea aerului din interiorul muzeelor şi conservarea operelor de artă din materiale textile. Studiu de caz: Casa-muzeu Sălacea, România/ Indoor air quality of museums and conservation of textiles art works. Case study: Salacea Museum House, Romania, 1/2019, 88-93 http://www.revistaindustriatextila. ro/images/2019/1/Industria\%20textila\%20no\%201_2019_web.pdf

Ionescu, M.F., Popescu, J., \& Dumitrescu, I. (2016). The tourist map, scientific tool that supports the exploration of protected areas. GeoSport for Society, 4(1), 24-32. https://www.researchgate.net/publication/304416404

Janaleyeva, K.M. (2010). Physical geography of the Republic of Kazakhstan. Astana: ENU named after L.N. Gumilyov, "Arkas".

Kabiyev, Y.S., Berdenov, Z.G., Dzhanaleeva, K.M., Atasoy, E., \& Wendt, J.A. (2018). Landscape ecological analysis of the modern delta of the Ural (Zhayik) river. GeoJournal of Tourism and Geosites, 23(3), 644-655. https://doi.org/10.30892/gtg.23302-316

Kalmenova, U.A. (2000). Fizicheskaya geografiya Kazakhstana. Tsentral'nyy Kazakhstan [Physical geography of Kazakhstan. Central Kazakhstan]. ZhezU, Kazakhstan, 80, (Russian).

Mikhaylov, A.S., Wendt, J.A., Peker, I.Yu., \& Mikhaylova, A.A. (2020). Spatio-temporal patterns of knowledge transfer in the borderland, Balt. Reg., Vol. 12, no 1, p. 132-155. https://doi.org/10.5922/2078-8555-2020-1-8

Mukayev, T.Zh., Ozgeldinova, O.Zh., Janaleyeva, M.K., Ramazanova, Ye.N., \& Zhanguzhina, A.A. (2020). Assessment of the tourist recreation capacity of lake Alakol basin. GeoJournal of Tourism and Geosites, 30(2spl), 875-879. https://doi.org/10.30892/gtg.302spl13-517

Nazarova, T.V., Fomin, I.A., Dmitriev, P.S., Wendt, J.A., \& Janaleyeva, K.M. (2019). Landscape and limnological research of lake systems of the plain areas of the Northeastern Borderlands of the Republic of Kazakhstan and assessment of their recreational capacity. GeoJournal of Tourism and Geosites, 25(2), 485-495. https://doi.org/10.30892/gtg.25217-375

Ozgeldinova, Z.O., Janaleyeva, K.M., Auyezova, Z.T., Mukayev, Zh., Saipov, A., Ospan, G.T., \& Kaygusuz, M. (2019). Assessment of human impacts on geosystems of sarysu river basin. Fresenius Environmental Bulletin, 28(8), 6019-6026. https://www.researchgate.net/publication/334537841 _ASSESSMENT_OF_HUMAN_IMPACTS_ON_GEOSYSTEMS_OF_SARYSU_RIVER_BASIN

Ozgeldinova, Z., Janaleyeva, K., Auyezova, Z., Mukayev, Z., \& Ramazanova, N. (2015). The present-day geoecologic situation of Kenghir river basin geosystems. Biosciences, Biotechnology Research Asia, 12 (3), 3041-3051 p. http://dx.doi.org/10.13005/bbra/1987

Ramazanova, N.Y., Berdenov, Z.G., Ramazanov, S.K., Kazangapova, N.B., Romanova, S.M., Toksanbaeva, S.T., \& Wendt, J. (2019). Landscapegeochemical analysis of steppe zone basin Zhaiyk. News of the National Academy of Sciences of the Republic of Kazakhstan, Series of Geology and Technical Sciences, vol. 4 (436), pp. 33-41. doi.org/10.32014/2019.2518-170X.95

Ramazanova, N., \& Dzhanaleyeva, G. (2012). Problems of Integrated Assessment of Geo-ecosystems of Steppe Zone of Ural River Basin, in Journal of Environmental Science and Engineering, B1, pp. 1037-1043.

Stepanova, S.A. (2010). Turistko-recreacionnye territorii: napravleniya issledovaniy, metody ocenki privlekanelnosti, principy postroyeniya reitinga [Tourist and recreational territories: research directions, methods of evaluating attractiveness, principles of rating construction]. Vestnik INZHKONa. Seriya Economika, 1 (36), 66 - 72, (Russian).

Tătar, C.F., Herman, G.V., \& Gozner, M. (2018). Tourist guides' contribution to sustainability in Romania. GeoJournal of Tourism and Geosites, 21(1), 282287. https://doi.org/10.30892/gtg.21122-287

Wendt, J.A. (2016). Tourism development challenges on the Dead Sea shore. Limnological Review, no. 2(2016), p. 105-112. https://www.researchgate. net/publication/312554726_Tourism_development_challenges_on_the_Dead_Sea_shore

Wendt, J.A., \& Bógdał-Brzezińska, Ag. (2018). Problematyka, metody i problemy badań w geografii turystycznej Turystyka: nowe trendy. Publisher: Polska Izba Turystyki Oddziat w Gdańsku, 7, 7-42 (in Poland). 